\title{
Gerald Malcolm Stern b.1930 d.2018
}

\section{Neurologist and scientist}

\author{
Peter Jenner ${ }^{1}$. Andrew Lees ${ }^{2}$
}

Published online: 11 March 2020

c) Springer-Verlag GmbH Austria, part of Springer Nature 2020

Gerald Stern was a doyen of clinical neurology of international repute who made numerous significant contributions to neurology and the field of movement disorders. His early life and career in neurology have been documented in other published eulogies (Lees 2018a, b; Quinn 2019; Lees and Ockelford 2019) — we would urge you to read these as they tell a compelling story of his upbringing, his entry in to medicine, and the start of his love affair with clinical neurology that contains object lessons for those about to embark on a similar voyage. For those of you who never met Gerald or heard him speak and have not read any of his numerous publications, you should indulge yourselves by reading one of his later works (Stern 2011) or the Stanley Fahn Lecture presented at the MDS meeting in 2010 in Buenos Aries which you can watch on YouTube (Stern 2010) and an interview carried out by Niall Quinn (Quinn 2010) following that presentation. Then, you will realise what a master of the English language he was, his intellect, his ability to dissect and analyse complex areas of neurology, and how he used his wit and humour to entertain an audience. Gerald showed boundless enthusiasm for clinical neurology and was beloved by his patients who adored the time and patience which he showed in trying to understand their problems and to treat them to the best of his ability. Such was the respect of his patients that two apparently penniless, little old ladies left him substantial legacies with which he funded his research. Famed for his tact and diplomacy and courteous manner, he was sought out by the rich, the famous, Kings, Presidents, and Popes for his clinical skills. Asked why he preferred to practice private medicine rather than

Peter Jenner

peter.jenner@kcl.ac.uk

1 Institute of Pharmaceutical Sciences, Faculty of Life Sciences and Medicine, King's College, London SE1 1UL, UK

2 The National Hospital, Queen Square, London WC1, UK aim for a chair of neurology, he responded in typical fashion 'My dear boy, I couldn't possibly afford to be a professor'. A pioneer and a non-conformist-some would say rebel-he was involved in the earliest studies of L-dopa in Parkinson's disease and subsequently in the introduction of dopamine agonist drugs, notably apomorphine and bromocriptine. Probably, he would have been most proud of his contribution to the introduction of the MAO-B inhibitor deprenyl in to the treatment of Parkinson's disease, which included being his own guinea pig for testing the safety and effect of the drug — unthinkable in the modern era.

Less well known is Gerald's love of science and laboratory-based research which was fostered by periods in his early career that he spent in USA and in Paris. He must have been one of very few clinicians who subscribed to and read Nature and Science on a regular basis. Enthused by articles that stimulated his imagination, he would be immediately on the telephone to discuss the details of the experiments or he would buttonhole people at meetings and have long conversations which showed the depth of his knowledge and his deep understanding of the relevance to clinical neurology. He would enthuse and even cajole his basic science colleagues in to action to exploit these latest ideas and to translate them in to practical solutions for his patient population. Gerald always described himself as 'a simple clinician', but those who worked with him found that he was far from that and including him in the basic science team raised novel ideas and concepts that his lateral thinking brought to the table.

Gerald was involved in early studies on the function of the substantia nigra and sub-thalamic nucleus inducing electrolytic lesions in primates under the tutelage of Fred Mettler at Columbia University in New York. This formed the basis of his MD thesis which he wrote sitting on a bidet in a former bordello in Paris. He later forged long-term relationships with Professor Merton Sandler at Queen Charlottes Hospital, London studying catecholamine metabolism and, 
subsequently, the actions and metabolism of deprenyl. He then became fascinated by the potential for curing Parkinson's disease through the use of foetal cell transplantation and in many respects was a pioneer in this field enabled by another long-term relationship with Professor Harry Bradford at Imperial College London. One of us (PJ) has personal experience of how Gerald never let an unsolved problem rest. One of his earliest studies, in 1963, was in to the cause of nigro-pallidal degeneration in horses induced by the ingestion of the yellow star thistle. Gerald tried unsuccessfully to induce the same degenerative process in both rodents and primates convinced that there was a specific toxin in the plant that had relevance to human disease. Some 30 years later, when MPTP was first coming to prominence, he related these studies to me, and after reading his paper, I was sufficiently convinced by Gerald's enthusiasm to go back to the problem. Together with a Swiss phytochemist, toxic components of the plant extracts were identified as sesquiterpene lactones (Cheng et al. 1992) —although it still remains a mystery as to why only horses are affected.

In his professional life, Gerald Stern was, by nature, a quiet, generous, and unselfish man who gave his time freely to others and was never one to seek the limelight. In fact, many will remember him because of the patronage which he showed to young neurologists and scientists encouraging them to greater things through his enthusiasm for the field. A gift that is not as common today and for which we are poorer. One of us (PJ) will be forever grateful for the support and encouragement that he received from Gerald in the early part of his career-everything from listening my woes to constructive criticism of my work to bombarding me with ideas to ensuring that I took the right path to achieve my ambitions. He was a father figure to many, but never took the credit for doing so much to advance the field of movement disorders in the UK and on an international basis. Perhaps, in these young people, he recognised something of himself and saw their struggles as the ones which he himself had had to overcome.

One or two final quotations personify Gerald and his personality. 'Surround yourself with clever young people who are more industrious, more imaginative, more intelligent than yourself' and 'Be nice to old ladies'.

Rest in peace dear friend!

\section{References}

Cheng CH, Costall B, Hamburger M, Hostettmann K, Naylor RJ, Wang Y, Jenner P (1992) Toxic effects of solstitialin A 13-acetate and cynaropicrin from Centaurea solstitialis L. (Asteraceae) in cell cultures of foetal rat brain. Neuropharmacology 31:271-277

Lees AJ (2018a) In memoriam: Gerald Malcom Stern (October 9, 1930-September 9, 2018). Mov Disord 33:1831-1833

Lees, AJ (2018b) Munk's Roll vol. XII, Royal College of Physicians, London. https://history.rcplondon.ac.uk/inspiring-physicians/geral d-malcolm-stern. Accessed Feb 2020

Lees AJ, Ockelford J (eds) (2019) Remembering Gerald Stern. Virginia Keiley Benefaction, London

Quinn N (2010) Interview with Gerald Stern, Buenos Aries, MDS Archives. https://www.youtube.com/watch?v=EST-Otslc8g. Accessed Feb 2020

Quinn N (2019) Gerald Malcolm Stern: 9th October 1930-9th September 2018. Mov Disord Clin Pract 6:9-10

Stern G (2010) Stanley Fahn Lecture, MDS Meeting, Buenos Aries. https://www.youtube.com/watch?v=q0_MZWVK3mE. Accessed Feb 2020

Stern G (2011) Why catechol? Mov Disord 26:24-26

Publisher's Note Springer Nature remains neutral with regard to jurisdictional claims in published maps and institutional affiliations. 